\title{
Lecturers' Perceptions of Factors that Attract Talent in a Ghanaian Higher Learning Institution
}

\author{
Justice Solomon Korantwi-Barimah ${ }^{1}$, Alex Ofori ${ }^{1}$, Faisal Mohammed ${ }^{1}$, \\ Emmanuel Addai Kyeremeh ${ }^{2}$
}

${ }^{1}$ Faculty of Business and Management Studies, Sunyani Technical University, Sunyani, Ghana

${ }^{2}$ Registry Department, Valley View University, Techiman Campus, Techiman, Ghana

Email address:

korantwi75@yahoo.com (J. S. Korantwi-Barimah)

\section{To cite this article:}

Justice Solomon Korantwi-Barimah, Alex Ofori, Faisal Mohammed, Emmanuel Addai Kyeremeh. Lecturers' Perceptions of Factors that Attract Talent in a Ghanaian Higher Learning Institution. Journal of Human Resource Management. Vol. 7, No. 1, 2019, pp. 1-10. doi: $10.11648 /$ j.jhrm.20190701.11

Received: October 2, 2018; Accepted: October 25, 2018; Published: May 7, 2019

\begin{abstract}
Creating a sustainable competitive advantage requires higher learning institutions to attract, motivate, develop and retain the talented staff they need now and in the future. However, the technical universities in Ghana are facing significant challenges in attracting and retaining talents to academic positions since their conversion. Besides, there exists limited research on factors that attract talented academics to these institutions as preferred employers. The main objective of this study was therefore to examine lecturers' perceptions of factors that attract talents to academic positions within a Ghanaian higher learning institution; in this instance, Sunyani Technical University (STU). A qualitative approach was adopted for this study; semi-structured interviews were conducted to gain data. The study participants comprised of 23 lecturers selected from the university under study. The findings show that nine themes are related to the attraction of talents to the universities: career development and advancement, opportunities to make a contribution, employer branding and prestige, job security, flexible working hours, intellectual stimulation, innovation, opportunity to apply skills and autonomy. The results challenge higher learning institutions to develop a superior employer brand with a strong employee value proposition (EVP) that would attract, develop and reward talented academics for their work efforts. The study provides important practical guidelines that could assist the university studied and other higher learning institutions to attract talented lecturers and become employers of choice.
\end{abstract}

Keywords: Talent Attraction, Employer Brand, Career Development, Lecturers' Perceptions, Technical Universities

\section{Introduction}

A major challenge facing the technical universities in Ghana remains the issue of attracting talented lecturers [1]. The persistent strikes, amidst issuing of ultimatums by unionized groups in the universities, especially the Technical University Teachers Association of Ghana (TUTAG), has significantly tarnished the reputation of the institutions as employers of choice. Though there has not been much fatalities, but lecturers suffered losses regarding performance bonuses, lack of quality lecturing time and decreased research productivity. Moreover, the organisational brands of the universities continue to be dented due to the downgrading of their competitive rankings relative to higher educational institutions abroad [2]. There is also a shrinking pool of resources to spend on talent. At the same time, lecturers contend with a lack of adequate research funding, uncompetitive remuneration packages and research incentives [3]. Consequently, tarnished organisational brands present serious barriers to attracting lecturers in ensuring an adequate pipeline of academics, which is critical to Ghana's national strategy to accelerate human capital development [4].

It is a very difficult task to identify talented lecturers. According to McAlpine and Akerlind, there are difficulties in trying to decide who talented lecturers are, what they do and how they develop as academics [5]. Most researchers in higher education agree that research involving lecturers has focused mainly on participants within the first five years or so of their first academic appointment. However, the nature of those appointments varies greatly. Equally worrisome is 
the fact that limited research exists on the factors that would attract talented lecturers to Ghanaian technical universities. Vale mentioned some factors that attract people to a career in academia, regardless of the financial implications, which include freedom to choose directions, reinventing oneself throughout one's career, participating in the great period of discovery, being part of an international community joined by common interests, pleasant travels, flexible daily schedule, and scholarship [6].

The rationale of the current study was therefore to examine lecturers' perceptions of factors that attract talented lecturers to Ghanaian technical universities. This study was motivated by the fact that little research has been conducted on the talent management of lecturers and the factors that attract them to these universities as a preferred employers. Thus, the study contributes to the limited research on the factors that attract talented lecturers to institutions of higher learning.

\section{Literature Review}

Literature on factors that attract talented lecturers was reviewed under the following sub-themes:

\subsection{Opportunity to Make a Contribution}

The technical universities in Ghana are expected to play a critical role in the development of human resources and in the overall socio-economic and developmental transformation of the country. As argued by Grobbelaar and De Wet, the success and sustainability of universities in fulfilling these roles depend on an academic profession that can utilise research, teaching and community engagement in solving problems and harnessing the full economic potential of the continent [7]. Similarly, studies have shown the important role of lecturers in advancing the employability skills of students [8]. Other research advocates the growing importance of involvement of academic staff in community service projects addressing contemporary societal needs [9]. Studies focusing on human-centric occupations indicated that individuals join the teaching profession because of the enhanced opportunity to interact with students and make a contribution towards the improvement of their lives [10].

Additionally, lecturers are challenged to advance their subject matter expertise to meet the knowledge requirements of the 21st century workplace [11]. Pienaar and Bester stated that the opportunity to make a meaningful contribution should not only be limited to student involvement, the community and the body of knowledge in a field. Rather, lecturers should be allowed to make contributions based on performance goals that are part of the job description and receive rewards in the form of bonuses, promotions, salary increases and recognition [12].

\subsection{Career Development and Advancement}

According to De Vos, Dewettnick, and Buyens, career management is a critical pillar of work-related outcomes linked to organisational commitment [13]. Gong and Chang stated that organisational opportunities and benefits should make employees feel obliged and committed to an organisation [14]. Bhatt argued that career anchors can assist in managing and steering career development and advancement of lecturers [15]. Career anchors are patterns of self-perceived talents, attitude, motives and values that guide and stabilise a person's career after several years of real world experience and feedback [15]. These should be supported by institutional human resource processes related to developing staff interest, opportunity to improve academic qualifications, availability of promotion opportunities and rapid career development opportunities for academics. Bhatt further suggested that organisations should revisit the way employees' careers are managed to ensure career progression through planning and organisational career management processes [15].

Although the concept of career management has received great research attention over the years, the career development of lecturers has been neglected. Available research shows that the careers of lecturers can be advanced through a variety of methods, such as mentorship [16], networking [17], transnational collaboration [18], training and development [19], opportunities for further education and promotion opportunities [15]. However, other research also pointed out that career development opportunities in universities are hampered by a lack of both government funding [20] and organisational infrastructure [21]. Collaborative research appears to be the appropriate strategy to promote career development of lecturers. Kochan and Mullen in Tynan and Garbett stated that collaboration enriches personal and organisational life as a whole, which is relevant for the development of new academics, regardless of gender [21]. The greatest advantage of collaborative research is that it provides a synergy that gives young researchers an entry into their field, with fewer mistakes and disappointments and less stress.

\subsection{Organisational Branding, Prestige and Employee Value Proposition (EVP)}

According to Hanover Research, universities are paying more attention to their marketing and branding functions because of the shortage of qualified lecturers. An employment brand represents an organisation's employee value proposition (EVP), which includes the gains that staff members enjoy in return for their efforts in the workplace [23]. Black, Manohar and Stehli identified four categories of benefits that represent $80 \%$ of what employees care about: leaders, the company, the job and the rewards [24]. A study by Annapoorna among management colleges in Turkey showed such factors as attractive salary, popularity of the institution, career growth, supportive work environment, recognition of work and work-life balance represent a compelling employment brand [25]. Saurombe, Barkhuizen and Schutte found that managers of higher educational institutions believe that factors such as reputation and image, organisational culture and identity, strategic vision, corporate social responsibility and work and surrounding environment 
are core to establish a compelling employment brand for talented academics [26]. A study by Lichy and Pon showed that the opportunity for lecturers to make their own decisions regarding their work enhanced their views of the employer brand [27].

\subsection{Flexible Working Hours (Work-Life Balance)}

Fisher contends that university teaching has traditionally been viewed as a relatively stress-free occupation [28]. Although not highly paid in comparison to that of professionals in the industrial sector, lecturers have been coveted for their tenure, light workloads, flexibility, perks such as overseas trips for study and/or conference purposes, and freedom to pursue their own research [29]. According to Padmasiri and Mahalekamge, balancing work and family life is an important factor in the personal and career development of academics [30]. Work-life conflict occurs when work and non-work demands are incompatible [31]. Bell, Rajendran and Theiler found that mounting stress and pressures related to the changing higher educational environment affects the work-life balance of lecturers [32]. A study by Noor showed that satisfaction with work-life balance was a significant predictor of academic turnover intentions in Malaysian public higher education institutions [33].

\subsection{Intellectual Stimulation and Innovation}

Goff contends that talent includes the right combination of inborn abilities, complemented by the knowledge, skills, attitudes and experience required to perform in a given situation [34]. Consequently, Foreman asserts that talented employees should not only be regarded as human capital but also as custodians of the success of their organisation through the implementation of their attributes. It therefore behooves on institutions to create a conducive environment within which employees will spontaneously want to share their human capital and talents [35]. Bendaraviciene, Kristolatitis and Turauskas found that academic work is largely driven by interest, intellectually challenging work, attentive supervision and good relations [36]. Moreover, the industry requires lecturers to become more innovative in terms of knowledge sharing and dissemination to facilitate teaching and learning [37]. There is the need for continuous professional development in teaching innovation for lecturers to meet the increasing educational demands of students as observed by Turner et al. [38].

\subsection{Job Security}

Job insecurity has become a key aspect of the technical universities in Ghana due to the current transformation and conversion processes. Results on the job security of lecturers are mixed and confounding. A study by Tessema showed that the availability of job opportunities in higher education institutions in Ethiopia increased the feelings of job security of academic staff members [39]. The results of this study however indicated that increases in job opportunities and subsequent higher student enrolments worsened working conditions of lecturers as they are confronted with increased workloads and extended work schedules. Pienaar and Bester found that job insecurity was a career obstacle for academic staff members in South Africa [12]. Similarly, Schulze found that a lack of job security had an adverse effect on the quality of research outputs produced by lecturers in a selected South African university [40].

\subsection{Autonomy}

Autonomy has to do with the opportunity to be able to make decisions and implement them with no or little interference by authorities. For academics, autonomy includes being permitted to teach and conduct research within their niche areas of interest, with all the required flexibility [41]. According to Schmidt and Landberg, academic freedom and autonomy are fundamental values of universities, as these affect all aspects of academic activity [42]. These authors further stated that autonomy can include the opportunity to teach without external influences and choosing one's own research projects and publication methods. A study by Clare and Sivil showed that transformation of institutions of higher learning has increasingly brought lecturers under surveillance and has significantly eroded their autonomy as individuals [43]. Ekundayo and Adedokun found that several factors can erode autonomy, such as the appointment of a vice chancellor, erosion of the powers of the academic board as a supreme body in academic matters and the issue of quota systems that force universities to take in students regardless of their qualification for admission [44]. Furthermore, Amarasena, Ajward and Ahasanul Haque found that a lack of autonomy has a significant impact on lecturers' satisfaction in government universities in Sri Lanka [45].

\section{Methodology}

\subsection{Research Design and Approach}

This study adopted a qualitative approach because of its emphasis on bringing forth the expectations and experiences of lecturers in a holistic and in-depth manner. According to Vishnevsky and Beanlands, this represents an exploratory analysis [46]. Furthermore, Kearney quoted in Vishnevsky and Beanlands [46] stated that an excellently pre-arranged and well-conducted qualitative research study serves as a reliable and rich source of knowledge that can be implemented by providing exploratory information about a phenomenon, promoting insight and awareness of human experience and supporting the development of formal frameworks and tools [46]. The present study took an interpretivist approach, which involved integrating human interest and experiences for interpretation [47]. This approach is considered suitable for qualitative evaluative research because it is useful, particularly, in intensive, smallscale research [48]. Researchers have contended that this approach should include a theoretical framework providing guidance on how to shape meaning derived from a particular 
belief into interpretable knowledge. According to Alvarez, the interpretivist method provides possibilities for generating fresh insights because it points out different facets of organisational phenomena and can produce significantly different and uniquely informative theoretical views of events [49].

\subsection{Research Strategy}

This study used a case study approach. One of the advantages of a case study is that it is more descriptive and exploratory in nature and less explanatory. This approach was considered appropriate for this study because, according to Yin, the empirical element of a case study method presents a phenomenon in a real-life context [50]. Silverman states that a case study's data analysis involves an iterative, spiraling or cyclical process that proceeds from a generalised perspective to more specific observations that can be generalized [51]. The approach for the present researchers was to generate and integrate themes derived from the interviews, in line with the conducted literature review. Munsamy and Bosch Venter observed that this approach is reliable and works consistently with the modernistic interpretivist strategy [52].

\subsection{Research Setting}

The setting for this study was one of the recentlyconverted technical universities in Ghana. Following the promulgation of the Technical Universities Act, 2016 (Act 922) [53], government of Ghana converted six out of the ten polytechnics into technical universities with a mandate to provide higher education in engineering, science and technology, applied art, technical and vocational education and training and other related disciplines and award its own degrees, diplomas, certificates and other qualifications agreed upon by the University Council with the approval of appropriate regulatory and certification bodies. Sunyani Technical University was selected for this study because of the fact that it is going through a critical conversion and transformation period.

\subsection{Sampling}

In this study, the participants comprised of 23 lecturers, selected from the university under study. In selecting the sample size, the following criteria were used: participants must have between 1 and 15 years of teaching experience, be academic staff and could be from any discipline and gender. This study adopted purposive sampling. Neuman postulates that purposive sampling enhances the understanding of what will be presented by the respondents and aids in developing theories and concepts [54]. Vishnevsky and Beanlands argued that, in qualitative research, the sample size is infrequently predetermined, and the researcher can include as many respondents as necessary to gain a comprehensive understanding of a phenomenon [46]. In this study, participants were selected based on their qualifications and experience [55], with a focus on who could provide the information needed for the study.

The demographic characteristics of the participants are shown in Table 1. Most of the participants were males $(\mathrm{N}=$ 16), employed as lecturers $(\mathrm{N}=23)$, and had a master's degree qualification $(\mathrm{N}=18)$.

Table 1. Demographic characteristics of interview participants.

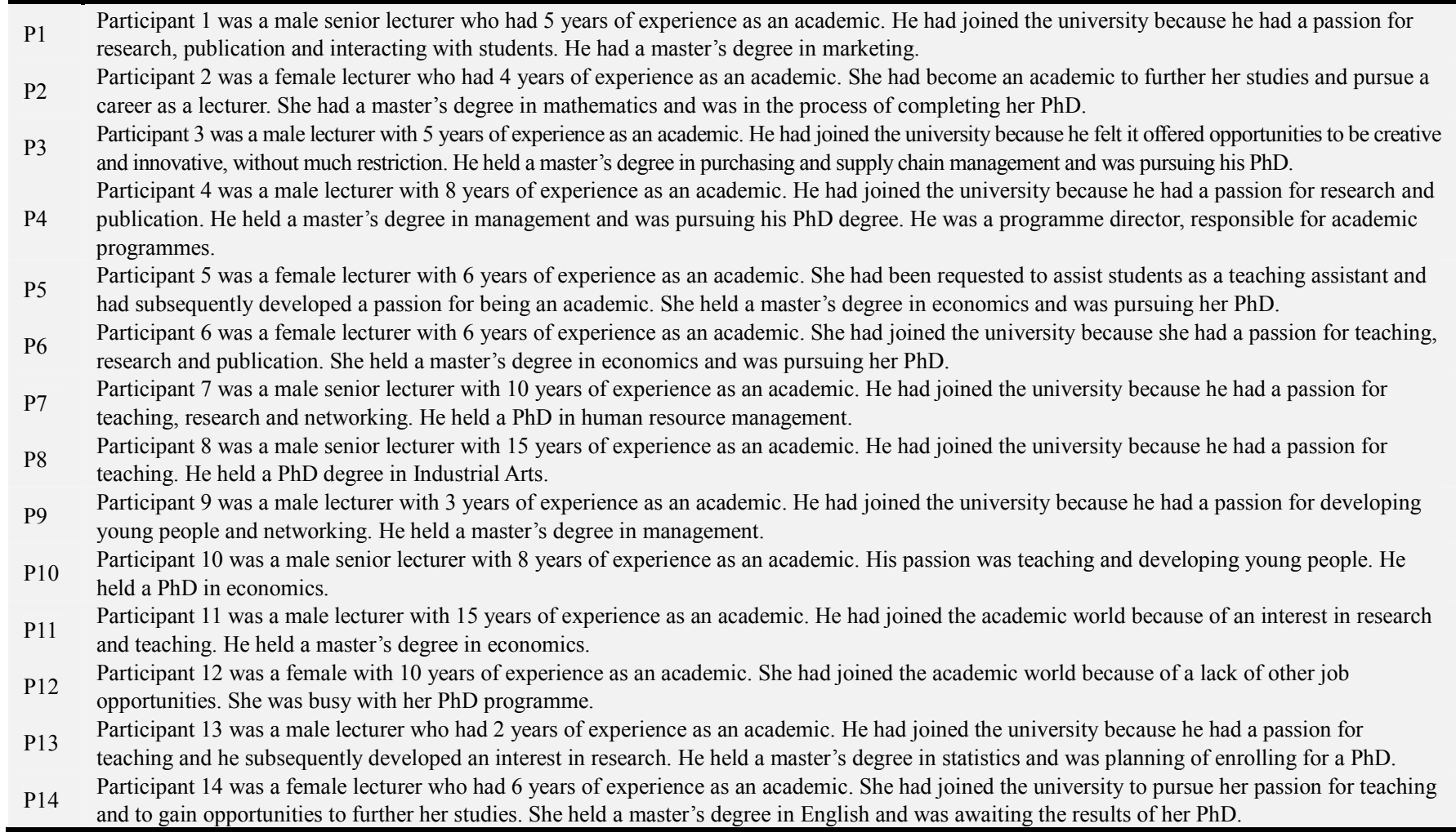




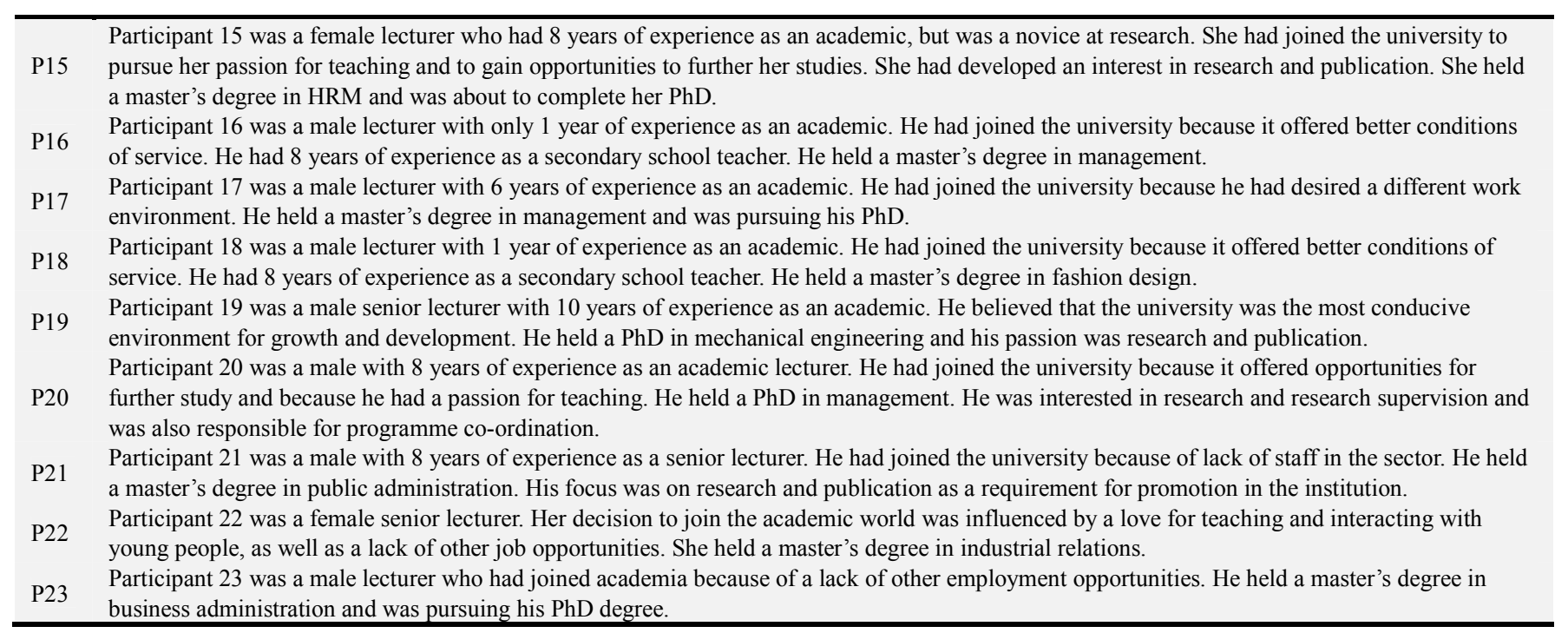

\subsection{Data Collection}

Data were collected through individual interview sessions. The interviews were conducted using structured questions, allowing consistency throughout the interviews. Neuman mentioned that structured questions assist the researcher in guiding participants in their discussions, which allow for the systematic collection of data on a defined area of interest [54].

\subsection{Data Recording and Storing}

The interviews were tape-recorded, which served as a backup system during data analysis. This ensured that the researchers did not draw incorrect conclusions from the responses. Extensive notes were taken, allowing recording of reactions to information by the participants. According to Rubin and Rubin, the above method gives respondents an indication that their input is important [47]. The notes taken during the interviews provide the researchers with an opportunity to monitor the data collection process and subsequent data analysis.

\subsection{Ensuring the Quality and Rigour of the Research}

In this study, the recorded interviews were transcribed. Notwithstanding the challenges encountered in transcribing all the recordings, all efforts were directed at ensuring that all relevant and important information were captured to safeguard the accuracy of data analysis. The quotes provided were verbatim.

In creating a framework for analysis, the researchers extracted themes and subthemes for the categorisation of information from the transcripts. Saunders, Lewis and Thornhill stated that this method allows the altering of themes and subthemes or relationships in the re-arranged data while searching for more information in the data [56]. Furthermore, this method allows for the identification of missing statements and justification of the alterations to the original implementation scheme, while allowing an up-todate definition of each theme and subtheme, to sustain consistency during data capturing and analysis [56]. The approach to the analysis entailed the researcher counting how many respondents mentioned the same issue, which is supported by [57].

\subsection{Reporting}

The findings of this study are reported in a table. The themes and subthemes extracted from the interviews are substantiated by direct quotes. This method is in line with the suggestion by Cresswell that a researcher should seek for support that a conclusion applies in a specific research context [58].

\section{Research Results}

The themes that emerged from the interview sessions and the frequency with which the themes emerged are presented in Table 2. The researchers identified nine themes from the combined responses of the participants. From the table, it is evident that career development and advancement, opportunities to make a contribution and employer branding and prestige were the themes that occurred most often.

Table 2. Frequency of themes.

\begin{tabular}{lll}
\hline Theme 1 & Career development and advancement & 23 \\
& Development in area of academic interest & 7 \\
& Opportunity to improve academic qualifications & 6 \\
& Availability of promotional opportunities & 5 \\
Theme 2 & Rapid career advancement opportunities & 5 \\
& Opportunity to make a contribution & 10 \\
& Contribution to students & 4 \\
Theme 3 & Contribution to community & 3 \\
Theme 4 & Job security & 3 \\
Theme 5 & Flexible working hours (work-life balance) & 4 \\
Theme 6 & Intellectual stimulation & 2 \\
Theme 7 & Innovation & 2 \\
Theme 8 & Opportunity to apply skills & 2 \\
Theme 9 & Autonomy & 2 \\
\hline
\end{tabular}

Theme 1: Career development and advancement 
Combined themes relating to career development and advancement occurred most often in this study. The participants stated that they were attracted to the university because of the opportunity to develop in an area of their academic interest. Some of the participants were more interested in establishing themselves as researchers.

A participant stated:

'There are a lot of structures and interventions that is available through the university, so I would like to develop very strongly as a researcher. Going forward, I've got a really clear picture of what it is that I want to do in my research. The university offers a number of fantastic opportunities for you to develop'. (Participant 11, male, lecturer, master's degree)

Other participants highlighted their interest in becoming educators. One participant stated:

'The thing that influenced me was this urge of contributing towards the educational and academic development. And then, also, to fulfil my personal need as an educator'. (Participant 7, male, senior lecturer, doctorate degree).

The participants furthermore suggested that opportunities should be created to attract students to academic positions. One of the participants stated:

'We can grow our team by developing those good students who obtain better grades to further their studies to become lecturers'. (Participant 12, female, lecturer, master's degree).

The participants also mentioned the availability of promotional opportunities and rapid career advancement as factors that attracted them to academia:

'The university systems are unlike the systems in government, where it is on the availability of the post, but, in academia, people get promoted depending on certain qualifications and meeting certain requirements'. (Participant 1, male, senior lecturer, master's degree)

Participant 1 also mentioned about opportunities for rapid career advancement and the benefits associated with it:

'Yes, if you are ready to work, it is an easier way to progress ... for every stage that you are promoted to, you definitely get better packages associated with it'.

Another participant mentioned:

'For PhD, definitely, because that was the ultimate of getting my PhD, and then I ... from here, it is now associate professor and then professor, and where else would you go than to a university'? (Participant 10, male, senior lecturer, doctorate degree)

The above comment was supported by Participant 2:

'For now, I'm really very busy with the PhD, and I think one is going to continue until you get to the highest level, to the professorship, and, when you get there, many opportunities open up for you'. (Participant 2, female, lecturer, master's degree)

The participants also highlighted the opportunity to extend their educational qualifications as a reason for joining the university. One participant stated:

'I think the opportunity to further my studies and the fact that I have a passion to work with students. I intend making a difference'. (Participant 20, male, senior lecturer, doctorate degree).

Theme 2: Opportunities to make a contribution

Combined themes related to opportunities to make a contribution occurred as the second most theme (mentioned ten times). These participants mostly joined the university to make a difference in the lives of their students.

One participant stated:

'The interest of being a lecturer started when I was a teaching assistant, so that's where I got my basis of being able to interact with students. I actually started loving the whole idea of helping students and the appreciation that you also get from the students, that's what inspired me to study further to become a lecturer'. (Participant 3, male, lecturer, master's degree)

In support of the above statement, Participant 5 added:

'Firstly, my interest is in empowering the students and inspiring them ... Second is more career-wise... Thirdly, it's all about passion. I'm not here by chance, I'm here by choice'. (Participant 5, female, lecturer, master's degree)

Furthermore, the participants were attracted to teach in the university to make a difference to the broader community and knowledge society. In this regard, some participants stated:

'The benefits are... it gives me a sense of knowing that I make a particular contribution towards the social economic development of our young and old. (Participant 7, male, senior lecturer, doctorate degree)

and

'It's nice to be called to give presentations, interviews, telling the whole world what certain issues are by giving you a platform to express your views. You have an opportunity to show what you have and who you are'. (Participant 8, male, Snr. lecturer, doctorate degree)

Theme 3: Employer brand and prestige

Employer branding and prestige was the theme that occurred third most (mentioned four times).

Some of the participants stated:

'This university must become an employer of choice, so that if you are an employer of choice, your employees are going to show commitment and engagement, and it seems we are on that way. Hopefully, we are going to continue in a manner of building our branding'. (Participant 6, female, senior lecturer, master's degree)

and

'I think the money aspect is not very attractive, but, comparatively, we will say the financial reward also makes one feel like joining here, and the prestige attached. At least, nobody would see you as an ordinary teacher and lecturer'. (Participant 5, female, lecturer, master's degree)

Other themes

Other themes that were mentioned less included job security, flexible working hours (work-life balance), intellectual stimulation and innovation (all mentioned twice), and opportunity to apply skills and autonomy (both mentioned once). The participants in this sample experienced job security because of contractual obligations to the university, related to their studies.

One of the participants stated: 
'...because of a sponsourship contract we signed, that we have to be here for a certain number of years... some of us have signed some bonds with the university, which we need to serve for about 3 or 5 years'. (Participant 2, female, lecturer, master's degree)

One of the participants cited flexible working hours and a sense of belonging to her department:

'Flexibility, as well... There's flexibility in terms of teaching, you know. Here it's more flexible, and growth, as well, in your department. You get so recognised that you just feel at home. You become a part of the family, and I think that is what you want the most'. (Participant 5, female, lecturer, master's degree)

The participants indicated that they were intellectually stimulated by the opportunity to gain knowledge. Consequently, one participant noted:

'I think, for me, it's all about trying to get as much knowledge as I can when it comes to academics, so, that's why I'm just pushing up until I get tired. Once getting that knowledge, I will impart it to other people'. (Participant 4, male, lecturer, master's degree).

\section{Discussions}

The main objective of this study was to examine lecturers' perceptions of factors that attract talented lecturers to Ghanaian technical universities. The participants identified nine factors that could be instrumental in the attraction of qualified academics: career development and advancement; opportunities to make a contribution; employer branding and prestige; job security; flexible working hours; intellectual stimulation; innovation; opportunity to apply skills and autonomy.

Career development and advancement was the practice that appeared to be the main factor in attracting talented lecturers to the universities. The participants further mentioned specific needs such as development in their area of academic interest, opportunities to improve their academic qualifications, the availability of promotional opportunities and rapid career advancement opportunities, as important for their career development. Although the universities had sufficient research infrastructures available [59], higher education management should create career development opportunities, such as mentorship, networking, transnational collaboration, specific training and development for teaching, and promotion opportunities that will assist young scholars to become professors and researchers of excellence [see 18, 60, 19]. Some participants also indicated the benefit of the possibility of obtaining further qualifications as part of being an employee at the university.

Opportunity to make a contribution occurred second most in this study. The participants specifically indicated that they wanted to make a contribution to students' lives, their community and the knowledge society. These findings indicate that these lecturers had clarity regarding the career expectations of an academic scholar and the purpose of their role as lecturers [7]. As found in previous research, the participants in the current study enjoyed interacting with students. They were also aware of social problems that students were exposed to, and were interested in empowering them to make a better life for themselves [10]. The participants were also of the view that the knowledge that they were disseminating could make a substantial contribution towards enhancing the broader society [12].

Employer branding and prestige emerged as the third most important factor. The participants emphasized the necessity for the university to improve its employer brand to ensure commitment by employees. These results are in line with the discoveries by Hanover Research [23], which indicated that universities should continue to improve their brand to attract quality academic staff. The participants also highlighted the improvement of the EVP of universities so that lecturers are rewarded sufficiently for their work efforts [26].

Other factors that were mentioned to a lesser extent included job security, flexible working hours, intellectual stimulation, innovation, opportunity to apply skills and autonomy. In line with previous studies, it appears that lecturers do not perceive higher education as an employer that will provide job security [40]. In the present study, autonomy was also not highlighted as a factor in the attraction of qualified lecturers. One possible explanation is that, unlike their senior colleagues, novice researchers do not yet have the responsibility to make independent decisions about their research endeavours [42]. The findings of the present study further confirm the importance of opportunity to apply skills and intellectual stimulation [see 35]. In contrast with previous studies, the lecturers in the present study did not consider work-life balance as a factor that would attract them to the university [30].

\section{Practical Implications}

The findings of this study have several important implications for the management of the university under study and all higher learning institutions. Firstly, it throws light on the factors that attract talented lecturers to Ghanaian universities. These findings challenge some traditional notions, suggesting that work-life balance and autonomy are not the main factors that would attract talented lecturers to the universities. From a practical perspective, this study therefore challenges the traditional structures of tertiary institutions and indicates that management of the universities should adopt talent management practices that cater for the diverse needs of young academics. The results further challenge Ghanaian technical universities to develop a superior employer brand with a strong EVP that would attract, develop and reward talented lecturers for their work efforts.

\section{Conclusion}

This study contributes to the HRM literature by revealing important information on the factors that will attract highlyqualified lecturers to the technical universities in Ghana. Importantly, it contributes to the limited research on the 
factors that attract talented lecturers to institutions of higher learning. As previously mentioned, the findings of this study challenge traditional knowledge and practices of recruitment in higher learning institutions. It is therefore advisable that management of the universities and HR departments redevelop talent management practices and policies in ensuring that qualified lecturers are attracted, developed and retained in support of the sustainability and competitiveness of the universities. These results offer several implications for both theory and practice. Thus, this study provides a stepping-stone for future research investigating talent attraction and retention in institutions of higher learning.

\section{Limitations and Future Research Suggestions}

Despite the strengths and new insight this study provides, the results do have several limitations that should be noted to improve future research. Firstly, the data consisted only of the perceptions of lecturers. As a result, the findings cannot be generalised to other staff members. Secondly, the study focused on the academic profession and thus the findings cannot be generalised to other sectors of the economy. Thirdly, the lack of research on the attraction of talented lecturers posed challenges in interpreting the results. It is therefore recommended that, for future research, managers of our universities should also be included in the sample in order to determine their perceptions of talent attraction, compared to those of lecturers. Similarly, a comparative study could be conducted between different academic groups to gain a holistic view on the factors that could attract lecturers to Ghanaian universities. It is further recommended that more research should be conducted on the attraction of lecturers for purposes of theory building.

\section{References}

[1] Korantwi-Barimah, J. S. (2017). Factors influencing the retention of Academic Staff in a Ghanaian technical university. Human Resource Management Research, 7(3): 111-119.

[2] Mouton, N., Louw, G. P., \& Strydom, G. L. (2013). Presentday dilemmas and challenges of the South African tertiary system. International Business \& Economics Research Journal, 12(13), 285-300.

[3] National Council for Tertiary Education (2016). Technical Report Series, 3, 2015/6. Accra, Ghana.

[4] Accelerated Development Plan (2010). Government of Ghana Policy, September, 2010.

[5] McAlpine, L., \& Akerlind, G. (2010). Becoming an academic: International perspectives. Basingstoke, UK: Palgrave Macmillan.

[6] Vale, R. D. (2010). It's a wonderful life: A career as an academic scientist. Molecular Biology of the Cell, 21(1), 1114. https://doi.org/10.1091/mbc.E09-08-0678.
[7] Grobbelaar, S., \& De Wet, G. (2016). Exploring pathways towards an integrated development role: The University of Fort Hare. South African Journal of Higher Education, 30(1), $162-187$.

[8] Heerde, J., \& Murphy, B. (2009). Work-integrated learning: An annotated bibliography of recently published refereed journal articles (2000-2008). Melbourne, Australia: Deakin University.

[9] Sanjobo, N., Lukwesa, M., Kaziya, C., Tepa, C., \& Puta, B. (2016). Evolution of HIV and AIDS programmes in an African institution of Higher Learning: The case of the Copperbelt University in Zambia. Open Aids Journal, 10, 24 33.

[10] Strauss, M. (2012). Talent attraction and retention of quality secondary school teachers to the rural areas of the Northern Cape province of South Africa. Dissertation submitted in partial fulfilment of the requirements for the degree M Com Industrial Psychology, Faculty of Economic and Management Sciences, University of Pretoria.

[11] Du Preez, R. (2015). Towards a 21st century university: Teachings from consumer behaviour applicable to higher education. South African Journal of Higher Education, 29(5), 140-155.

[12] Pienaar, C., \& Bester, C. L. (2008). The retention of lecturers in the early career phase: Empiricalresearch. SA Journal of Human Resource Management, 6(2), 32-41.

[13] De Vos, A., Dewettinck, K., \& Buyens, D. (2007). To move or not to move? The relationship between career management and preferred career moves. Employee Relations, 30(2), 156175 .

[14] Gong, Y., \& Chang, S. (2008). Institutional antecedent and performance consequences of employment security and career advancement practices: Evidence from the People's Republic of China. Human Resource Management, 47(1), 33-48.

[15] Bhatt, A. S. (2011). A career anchor perspective of employees in a large company. In 2011 International Conference on Advancements in Information Technology (pp. 265-270). With workshop of ICBMG 2011. IPCSIT Vol. 20 (2011) $^{\circ}$ (2011). Singapore: IACSIT Press.

[16] Thomas, J. D., Lunsford, L. G., \& Rodrigues, H. A. (2015). Early career academic support: Evaluating mentoring networks. Journal of Higher Education Policy and Management, 37(3), 320-329.

[17] Ansmann, L., Flickinger, T., Barello, S., Kunneman, M., Mantwill, S., Quilligan, S., Aelbrecht, K. (2014). Career development for young academics: Benefits of networking and the role of professional societies. Patient Education and Counseling, 97, 132-134. https://doi.org/10.1016/j.pec.2014.06.013.

[18] Coldwell, D., Papageorgiou, E., Callaghan, C., \& Fried, A. (2016). Academic citizenship and wellbeing: An exploratory cross-cultural study of South African and Swedish academic perceptions. South African Journal of Education, 30(1), 80105. https:// doi.org/10.20853/30-1-555.

[19] Botha, L. S., \& Potgieter, F. J. (2009). Understanding skills development in South African HigherEducation Institutions. South African Journal of Higher Education, 23(2), 28-45. 
[20] Busch, R., \& Ledingham, M. (2016). Bothered bloggings and troubled tweets: Constructions of stress and concerns for early-career academics. First International Conference on Advanced Business and Social Sciences, 1, 1-12.

[21] MacGregor, K. (2009). South Africa: Shocking results from university tests. University World News. Retrieved from http://www.universityworldnews.com/ article.php?

[22] Tynan, B. R., \& Garbett, D. L. (2007). Negotiating the university research culture: Collaborative voices of new academics. Higher Education Research and Development, 26(4), 411-424.

[23] Hanover Research. (2014). Trends in higher education marketing, recruitment and technology. Retrieved December 15, 2017 from http://www.hanoverresearch.com/ media/Trends-in-Higher-Education-Marketing-Recruitmentand-Technology-2.pdf

[24] Black, J. S., Manohar, M., \& Stehli, S. (2013). The war for leadership talent: Creating a superior employee value proposition. Lausanne, Switzerland: International Institute of Management Development.

[25] Annapoorna, M. S. (2015). A study on employer branding with reference to higher education sector in Tumkur city with special focus on management colleges Tumkur city. International Multidisciplinary E-Journal, 4(8), 285-294.

[26] Saurombe, M., Barkhuizen, E. N., \& Schutte, N. (2017). Management perceptions of a higher educational brand for the attraction of talented academic staff. South African Journal of Human Resource Management, 15, 1-10. https://doi.org/10.4102/ sajhrm.v15i0.831.

[27] Lichy, J., \& Pon, K. (2015). For better or for worse: The changing life of academic staff in French business schools. Journal of Management Development, 34(5), 536-552.

[28] Fisher, S. (1994). Stress in academic life: The mental assembly line. Buckingham: Open University Press.

[29] Gillespie, N. A., Walsh, M., Winefield, A. H., Dua, J., \& Stough, C. (2001). Occupational stress in universities: Staff perceptions of the causes, consequences and moderators of stress. Work and Stress, 15, 53-72.

[30] Padmasiri, M. K. D., \& Mahalekange, W. G. S. (2016). Impact of demographical factors on work life balance among academic staff of university of Kelaniya, Sri Lanka. Journal of Education and Vocational Research, 7(1), 54-59.

[31] Rana, S., \& Panchal, S. (2014). Work life balance of academic sector employees: A study in Vadodara City. Indian Journal of Applied Research, 4(6), 290-201.

[32] Bell, A. S., Rajendran, D., \& Theiler, S. (2012). Job stress, well-being, work-life balance and work-life conflict among Australian academics. Electronic Journal of Applied Psychology, 8(1), 25-37.

[33] Noor, K. M. (2011). Work-life balance and intention to leave among lecturers in Malaysian Public Higher Education Institutions. International Journal of Business and Social Science, 2(11), 240-248.

[34] Goff, S. (2008). Finding, developing and managing project talent: In today's top enterprises, everyone's a talent scout. Retrieved April 12, 2017 from www. ProjectExperts.com.
[35] Foreman, D. C. (2007). Harnessing the elusive asset: Developing intangible organizational capital. Retrieved June 19,2018 , from

http://www.workinfo.com/free/Downloads/libraryPaper_9864. pdf

[36] Bendaraviciene, R., Kristolatitis, R., \& Turauskas, L. (2013). Exploring employer branding to enhance distinctiveness in higher education. European Scientific Journal, 9(19), 45-78.

[37] Barrett, B. (2011). International conference on intellectual capital, knowledge management \& organisational learning. Paper published in the peer reviewed Conference Proceedings of the 8th International Conference on Intellectual Capital, Knowledge Management \& Organisational Learning, pp. 7582. Reading, UK: Academic Publishing Ltd.

[38] Turner, R., Spowart, L., Winter, J., Muneer, R., Harvey, C., \& Kneale, P. (2017). The lecturer should know what they are talking about: Student union officers' perceptions of teachingrelated CPD and implications for their practice. Innovations in Teaching International, 54(2), 143-151.

[39] Tessema, K. A. (2009). The unfolding trends and consequences of expanding higher education in Ethiopia: Massive universities, massive challenges. Higher Education Quarterly, 63(1), 29-45.

[40] Schulze, S. (2008). Academic research at a South African Higher Education Institution: Quality issues. South African Journal of Higher Education, 22(3), 629-643.

[41] Stromquist, N. P. (2017). Twenty years later: International efforts to protect the rights of higher education teaching personnel remain insufficient. MD: Education International, Brussels, Belguim.

[42] Schmidt, E. K., \& Langberg, K. (2008). Academic autonomy in a rapidly changing higher education framework. European Education, 39(4), 80-94.

[43] Clare, J., \& Sivil, R. (2014). Autonomy lost: The bureaucratisation of South African HE. South African Journal of Higher Education, 28(1), 60-71.

[44] Ekundayo, H. T., \& Adedokun, M. O. (2009). The unresolved issue of university autonomy and academic freedom in Nigerian universities. Humanity and Social Sciences Journal, 4(1), 61-67.

[45] Amarasena, T. S. M., Ajward, A. R. \& Ahasanul Haque, A. K. M. (2015). The effects of demographic factors on job satisfaction of university faculty members in Sri Lanka. International Journal of Academic Research and Reflection, 3(4), 89-106.

[46] Vishnevsky, T., \& Beanlands, H. (2004). Interpreting research in nephrology nursing. Nephrology Nursing Journal, 31, 234 238.

[47] Rubin, H., \& Rubin, I. (1995). Qualitative interviewing: The art of hearing data. Thousand Oaks, CA: Sage.

[48] Walker, E., \& Dewar, B. (2000). Moving on from interpretivism: An argument for constructivist evaluation. Journal of Advanced Nursing, 32, 1-12. https://doi. org/10.1046/j.1365-2648.2000.01532.x.

[49] Alvarez, S. (2003). Towards an interpretative integrative framework to conceptualise social processes in large information systems implementations. Information Technology for Development, 10, 233-247. https://doi.org/10.1002/itdj. 1590100403. 
[50] Yin, R. K. (2003). Case study research: Design and methods (3rd ed.). Thousand Oaks, CA: Sage.

[51] Silverman, D. (2000). Doing qualitative research: A practical handbook. London: Sage.

[52] Munsamy, M., \& Bosch Venter, A. (2009). Retention factors of management staff in the maintenance phase of their careers in local government. SA Journal of Human Resource Management, 7(1), 1-9.

[53] Technical Universities Act, 2016 (Act 922). Ghana Government Gazette, September 2016. Accra, Ghana.

[54] Neuman, W. L. (2003). Social research methods: Qualitative and quantitative approaches. Boston, MA: Pearson Education.

[55] Cooper, D. R., Schindler, P. S., \& Sun, J. (2006). Business research methods (Vol. 9). New York: McGraw- Hill Irwin
[56] Saunders, M., Lewis, P., \& Thornhill, A. (2003). Research methods for business students. London: Pearson Education Limited.

[57] Seidman, I. (2012). Interviewing as qualitative research: A guide for researchers in education and the social sciences. New York: Teachers College Press.

[58] Cresswell, J. W. (2009). Research design: Qualitative, quantitative and mixed methods approaches (3rd ed.). Thousand Oaks, CA: Sage.

[59] Singh, R. J. (2015). Current trends and challenges in South African higher education. South African Journal of Higher Education, 29(3), 1-7.

[60] Schulze, S. (2015). The doctoral degree and the professional academic identity development of female academics. South African Journal of Higher Education, 29(3), 260-276. 